Article

\title{
High Pressure Oxydesulphurisation of Coal—A Parametric Study
}

\author{
Moinuddin Ghauri ${ }^{1,2, *}$, Abrar Inayat ${ }^{1}$, Muhammad Tariq Bashir ${ }^{3}$, Salmiaton B. Ali ${ }^{3}$ \\ and Keith R. Cliffe ${ }^{2}$
}

1 Department of Chemical Engineering, COMSATS Institute of Information Technology, Defence Road, Off Raiwind Road, 54000 Lahore, Pakistan; E-Mail: abrar.inayat@gmail.com

2 Department of Mechanical and Process Engineering, University of Sheffield, South Yorkshire S10 2TN, UK; E-Mail: cliffekeith@gmail.com

3 Department of Chemical and Environmental Engineering, Universiti Putra Malaysia, Selangor 43400, Malaysia; E-Mails:gs32214@mutiara.upm.edu.my (M.T.B); mie@upm.edu.my (S.B.A)

* Author to whom correspondence should be addressed; E-Mail: drghauri@ciitlahore.edu.pk; Tel.: +92-42-111-001-007; Fax: +92-42-9920-3100.

Received: 11 December 2012; in revised form: 5 March 2013 / Accepted: 6 March 2013 / Published: 3 April 2013

\begin{abstract}
The current study is focused on controlling sulphur emissions by pre-treating coal to remove sulphur prior to combustion using the oxydesulphurisation technique. Three British coals were chosen for the study. Working with these coals gave a better insight to the oxydesulphurisation reactions for pyritic and organic sulphur. Effect of air and oxygen pressure in a fixed time interval on sulphur removal was studied by series of experimental runs at various temperatures. Heating value recoveries were significant. Increase in oxygen content is reported as a measure of carbon loss. The coal samples were analyzed according to British standard methods. Experimental results demonstrate that the sulphur removal was enhanced with the increase in air pressure, particularly up to 100 bars, with only a small decrease in calorific value at a particular temperature. Increasing temperature was witnessed to be more important in sulphur removal than increasing pressure.
\end{abstract}

Keywords: oxydesulphurisation; coal; pyritic sulphur; organic sulphur 


\section{Introduction}

Presence of impurities like sulphur and ash-forming minerals in coal affect its properties and thus detract from its value for most applications, including combustion, metallurgical processes, synthesis fuels etc. [1,2]. Sulphur in coal in both inorganic and organic forms is recognized as one of the major impurities in coal [3]. Out of the various inorganic forms, iron pyrite $\left(\mathrm{FeS}_{2}\right)$ is present either as discrete particles or finely disseminated throughout the coal, while organic sulphur is present as an integral part of the coal matrix [4].

The objective of coal cleaning is to remove sufficient sulphur and mineral matter to permit coal to be used for power generation without flue gas scrubbing [5-7]. Operationally convenient methods of controlling sulphur issues in line with the current emission legislation and the other coal application processes make chemical coal cleaning inevitable over and above physical cleaning methods $[4,8,9]$. Another advantage of chemical coal cleaning is that it also reduces the mineral matter and trace elements. A possible disadvantage is that the combustion properties can also be modified, due to the decrease in calorific value which is a result of the increase in the oxygen content, behavior of ash content and loss of organic matrix of the treated coal.

Technically chemicals are used to react selectively with the impurities to convert them into a soluble fraction, resulting in easy separation from the insoluble solid phase with which they were originally associated. All the leading chemical coal cleaning processes, in addition to sulphur removal, also result in a degradation of organic matrix to a certain degree, depending upon the leaching reaction conditions [10,11].

The fact that the quantity of coal to be treated is huge provides an incentive towards the development of a process dealing with relatively low product loss due to the leaching reaction as well as requiring low capital and operating costs of the treatment plant [12]. Thus a process should meet the following conditions:

1. Operate at or near ambient temperature to minimize energy requirements and limit degradation of the coal matrix;

2. The reaction should be fast in order to minimize residence time, which primarily determines the reactor size;

3. Above $90 \%$ product recovery;

4. Chemicals should be low in cost or by-products produced should have significant value.

Oxydesulphurisation processes meet several of these criteria by converting the sulphur into the form of soluble sulphates. Up to now oxydesulphurisation research has involved mainly high temperature reactions. Yaman and Kucukbayrak [13] studied the oxydesulphurisation behavior of a Turkish lignite under 0-1.5 MPa partial pressure of oxygen, $403 \mathrm{~K}$ and $498 \mathrm{~K}$ for 30-90 minutes kinetics using dilute alkaline solutions. Removal of sulphur and ash, TGA based combustion characteristics and DTG curves based effects on the coal combustion reactivity were reported. Palmer et al., [14] investigated the chemical desulphurisation of coals using selective oxidation with a mixture of hydrogen peroxide in acetic acid. In addition, Palmer et al., [15,16] characterized and studied the desulphurisation of oxidized and unoxidized coals via pyrolysis. Pietrzak and Wachowska [17] reported the characterization and the changes on the coal surface after oxidization using nitric acid. Furthermore, 
Pietrzak et al., [18] studied XPS of pyrite-free coals using different oxidizing agents e.g., peroxyacetic acid, oxygen and air at $125^{\circ} \mathrm{C}$. Jorjani et al., [19] investigated air, peroxyacetic acid (PAA), and PAA and air as a pretreatment for desulphurisation of Tabas coal from Iran with sodium butoxide in a batch reactor. The effects of air oxidation temperature, PAA oxidation time, sodium butoxide reaction time and temperature, solvent concentration and particle size on pyritic and organic sulphur removal were reported. A declining trend was observed in sulphur removal beyond $100{ }^{\circ} \mathrm{C}$. Demirbas [20] reported that alkaline desulphurisation is more effective in removing pyritic sulphur from coal. Limited studies have been carried out on oxydesulphurisation of coal at high pressure. This work is to study effect of high pressure for penetration to sulphur sites present deep in the coal matrix as a generic approach.

\section{Materials and Methods}

The coal samples used were obtained in small lump form of $<30 \mathrm{~mm}$ size. In order to prepare these samples for analytical and reaction work, first of all these samples were crushed to a smaller size in a jaw crusher and then ground in a Raymond hammer mill. Finally size separation was carried out by dry sieving using British Standard 410 sieves. Sample preparation was done following British Standard 1017 [21].

The coal sample mainly used in the oxidation reactions was from the Prince of Wales mine in Yorkshire (UK). This coal was selected as being reasonably typical high-sulphur British coal. Two batches of different particle sizes of this coal were used during this course of study. One batch was of average particle size $51 \mu \mathrm{m}$ and other was of average particle size $25 \mu \mathrm{m}$ that passed through $75 \mu \mathrm{m}$ and $63 \mu \mathrm{m}$ sieves, respectively. Both batches of this coal on average had a distribution of inorganic and organic sulphur of $52 \%$ inorganic and $48 \%$ organic sulphur. The two batches are characterized as Prince of Wales (POW) A and B. Apart from the Prince of Wales coal, investigations were also carried out using two more British coals, namely Silverdale and Harworth. Silverdale and Harworth coal samples were chosen for their high pyritic sulphur and ash content and were washing stage discards. The idea being that such discards are very cheap, so if the sulphur content could be minimized to meet current legislation, then these discards could become a low cost valorized product.

\subsection{Analytical Techniques}

The analyses of the coal samples pre- and post-oxidation reactions were performed according to British Standard methods [21]. Sulphur, carbon and hydrogen contents were determined by the methods described in British Standard 1016 [21], parts 6 and 11, while ash and gross calorific values (GCV) were obtained using British Standard 1016, parts 3 and 5, respectively. Particle sizing was carried out using a Malvern 2600/3600 particle size analyzer VA6, that reported particle sizes in Volume Mean Diameter (VMD). It should be noted that, it was not possible to determine the organic sulphur content directly so it was calculated by the difference between total sulphur and inorganic sulphur [Equation (1)]

$$
\mathrm{S}_{\mathrm{O}}=\mathrm{S}_{\mathrm{T}}-\mathrm{S}_{\mathrm{P}}-\mathrm{S}_{\mathrm{S}}
$$

where $\mathrm{S}_{\mathrm{T}}=$ Total Sulphur; $\mathrm{S}_{\mathrm{P}}=$ Pyritic Sulphur; $\mathrm{S}_{\mathrm{S}}=$ Sulphate Sulphur; $\mathrm{S}_{\mathrm{O}}=$ Organic Sulphur. 


\subsection{Calculations}

All the sulphur results reported are on an ash free basis, whereas the carbon, hydrogen and oxygen contents reported are on an "as such" basis. The percentages of pyritic, organic or total sulphur removed from coal were determined using Equations (2-4):

$$
\text { Desulphurisation }(\%)=\frac{S_{\mathrm{wt}}(\text { Feed })-\mathrm{S}_{\mathrm{wt}}(\text { Product })}{\mathrm{S}_{\mathrm{wt}}(\text { Feed })} \times 100
$$

The yield of desulphurised coal product was calculated as:

$$
\text { Coal Recovery } \%=\frac{\text { Dry wt. of Product }}{\text { Dry wt. of Feed }} \times 100
$$

The heating value recovery was calculated as the ratio of heating value of the oxidized coal to the heating value of untreated coal:

$$
\text { Recovery }(\%)=\frac{(\text { Wt. of coal recovered }) \times(\text { Product heating value })}{(\text { Wt. of feed stock }) \times(\text { Feed stock heating value })} \times 100
$$

\subsection{Reaction Procedure}

A 50 gm coal sample was weighed into the reaction vessel sleeve. The sample was slurried with one liter of distilled water to give a coal slurry concentration of $5 \% \mathrm{w} / \mathrm{v}$. This coal water slurry was then transferred into a two liter autoclave reactor. The slurry was then agitated using a three blade Marine impeller at a tip speed of $5 \mathrm{~Hz}$. In order to determine the effect of pressure and temperature, the reaction time of these experiments was fixed at one hour. The coal water slurry was then blanketed with nitrogen and the system was heated up to the required temperature using an electric heating coil wound around the reactor. The required system temperature was regulated by electronic controller. The system was then switched over to either air or oxygen. The required experimental pressure was regulated and monitored using a high pressure air/oxygen regulator and gauge. After completion of an experiment the reaction was quenched by venting the high pressure air/oxygen from the system and switching back to the nitrogen blanket. The whole system was then cooled down followed by venting the system to atmospheric pressure.

The coal-water slurries were filtered through a Buchner funnel. After filtration the cake obtained was re-slurried with distilled water, followed by the filtration step, repeated to a neutral $\mathrm{pH}$. The filter cake obtained after washing was dried overnight at $75^{\circ} \mathrm{C}$ in an oven. Finally the samples were air dried to a constant weight before analysis. A process flowsheet diagram is shown in Figure 1. The analysis of untreated coal is given in Table 1. 
Figure 1. Process flow diagram.

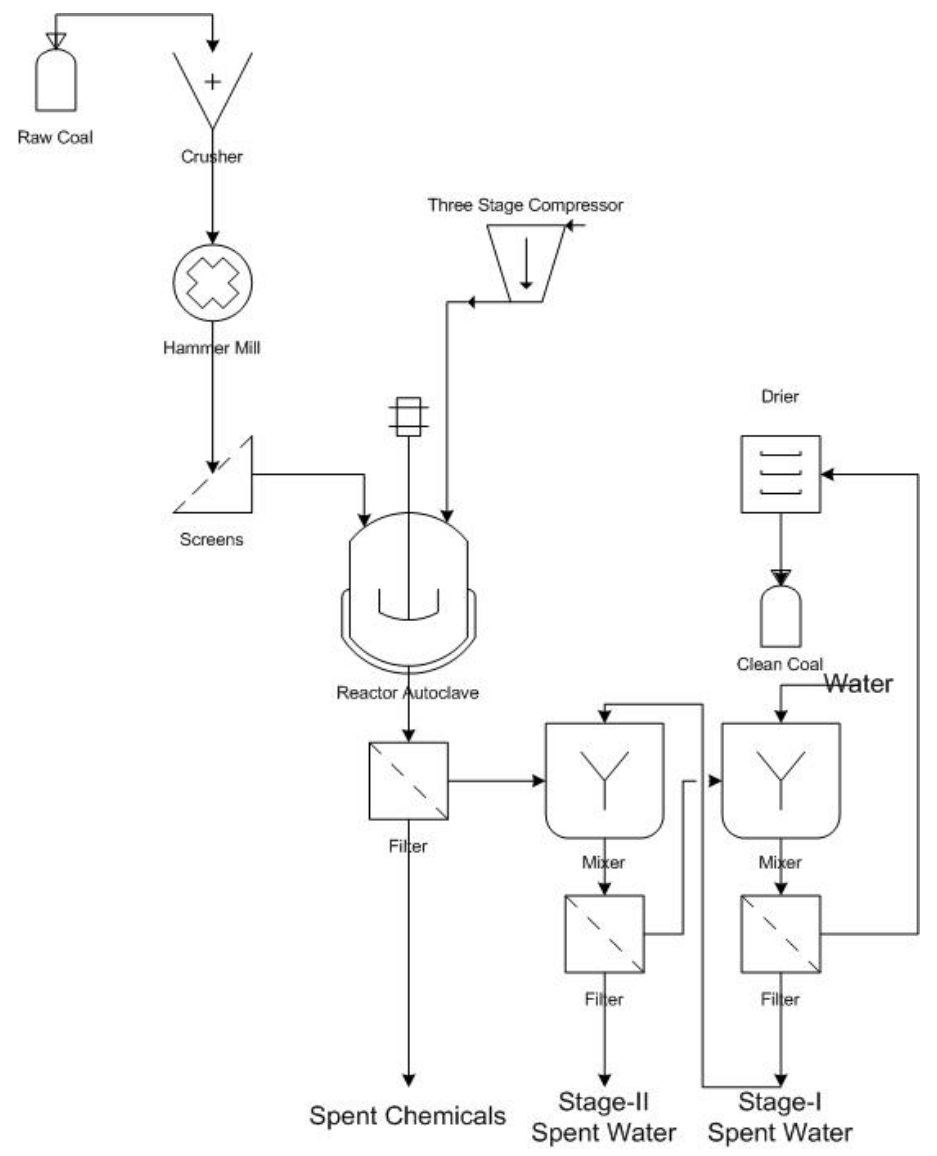

Table 1. Analysis of the untreated coals.

\begin{tabular}{lcccc}
\hline Parameter & POW* $(\mathbf{A})$ & POW $(\mathbf{B})$ & Silverdale & Harworth \\
\hline Total sulphur \% & 2.39 & 2.54 & 7.64 & 4.60 \\
Pyritic sulphur \% & 1.15 & 1.26 & 6.09 & 3.06 \\
Sulphate sulphur \% & 0.07 & 0.10 & 0.04 & 0.07 \\
Organic sulphur \% & 1.17 & 1.18 & 1.51 & 1.46 \\
Ash \% & 17.44 & 13.03 & 30.54 & 49.64 \\
GCV** $(\mathrm{kJ} / \mathrm{g})$ & 25.63 & 28.80 & 22.64 & 11.79 \\
Carbon \% & 68.79 & 71.04 & 55.61 & 29.64 \\
Hydrogen \% & 5.38 & 5.42 & 4.64 & 2.38 \\
Nitrogen \% & 1.00 & 1.00 & 0.56 & 1.00 \\
Oxygen \% & 2.09 & 4.21 & 0.44 & 10.86 \\
Particle size $(\mu \mathrm{m})$ & 51 & 25 & 24 & 23 \\
\hline
\end{tabular}

*POW $=$ Prince of Wales; ${ }^{* *} \mathrm{GCV}=$ Gross Calorific Value $\mathrm{kJ} / \mathrm{g}$.

\section{Results and Discussions}

\subsection{Effect of Air Pressure on Sulphur Removal}

These reactions were performed on Prince of Wales (A), Silverdale and Harworth coal samples. The reactions were carried out at three different temperatures varying from $40-100{ }^{\circ} \mathrm{C}$ and four different 
pressures varying from 50-300 bars. Figures 2-7 show the effect of air pressure on pyritic and organic sulphur removal, while the heating value recoveries are revealed in Figures 8-10.

Figure 2. Effect of air pressure on pyritic sulphur removal for Prince of Wales coal.

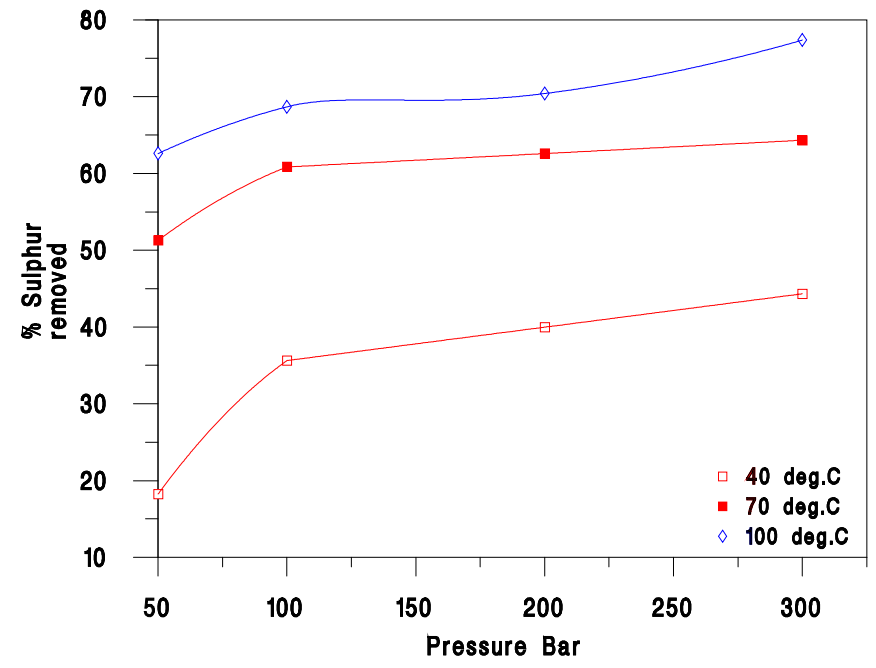

Figure 3. Effect of air pressure on pyritic sulphur removal for Silverdale coal.

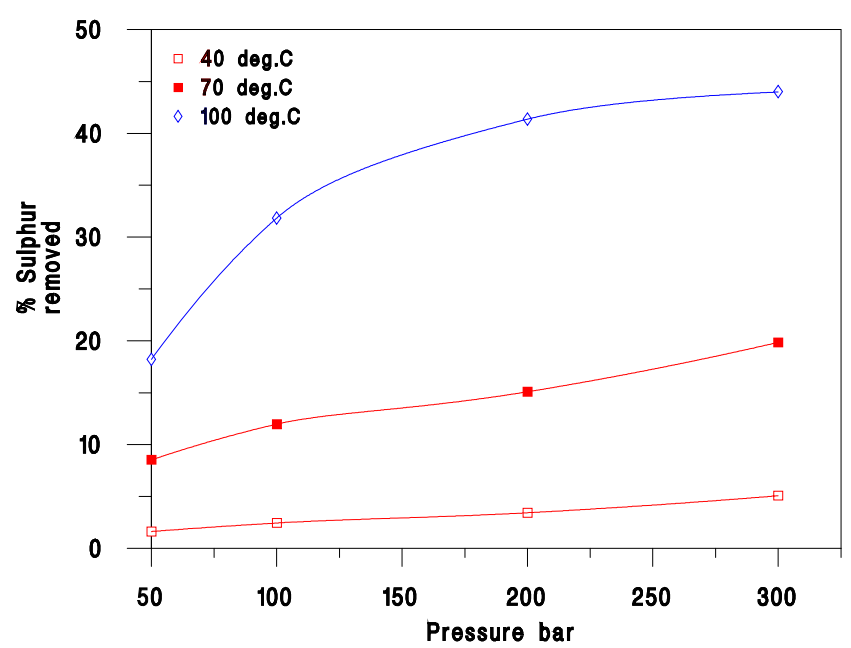

Figure 4. Effect of air pressure on pyritic sulphur removal for Harworth coal.

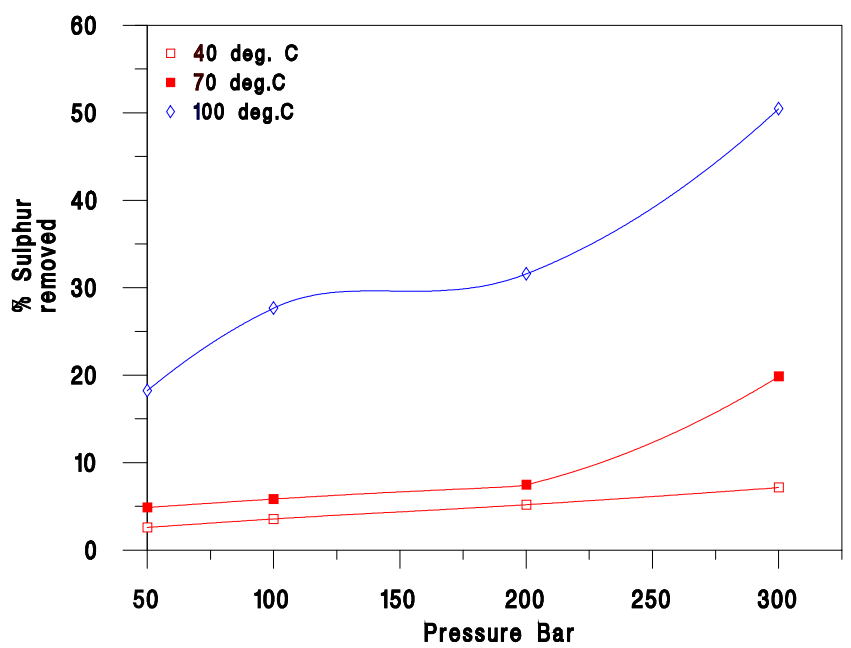


Figure 5. Effect of air pressure on organic sulphur removal for Prince of Wales coal.

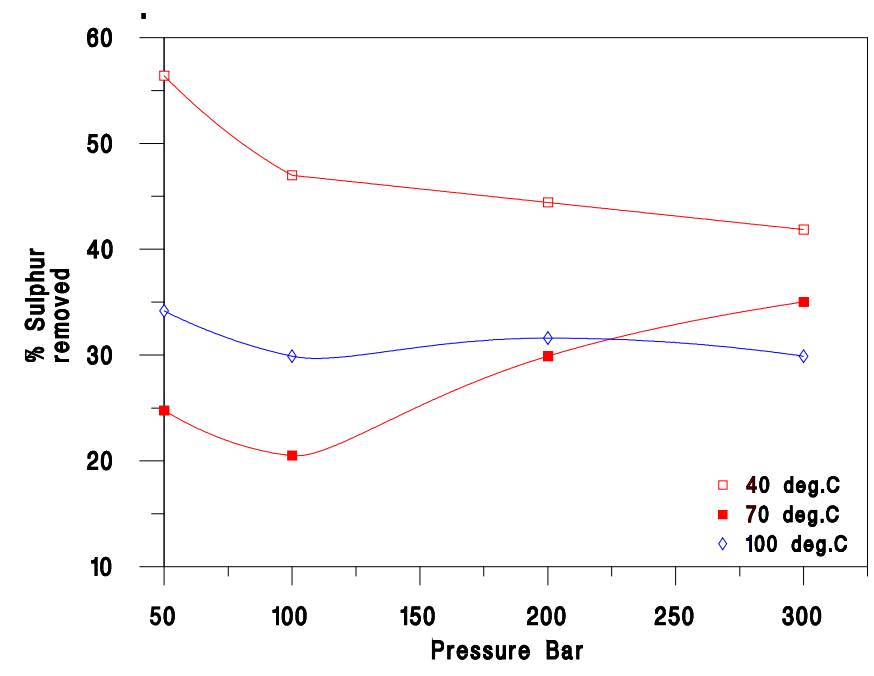

Figure 6. Effect of air pressure on organic sulphur removal for Silverdale coal.

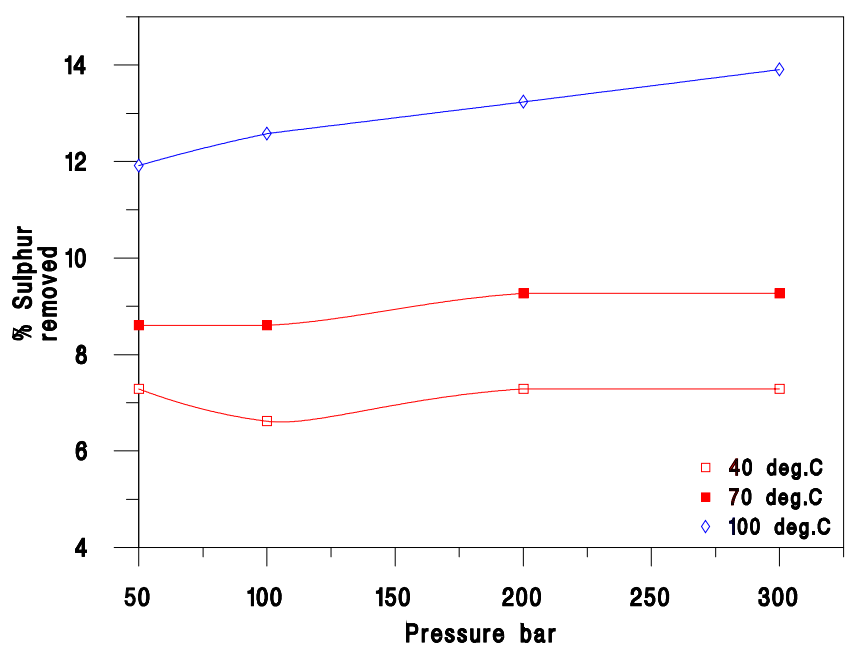

Figure 7. Effect of air pressure on organic sulphur removal for Harworth coal.

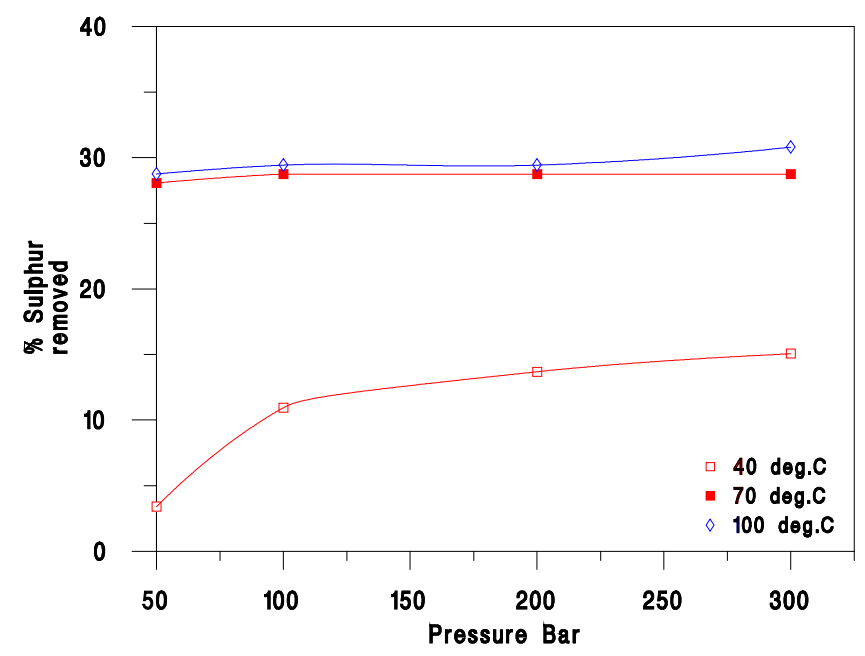


Figure 8. Effect of air pressure on heating value recovery of Prince of Wales coal.

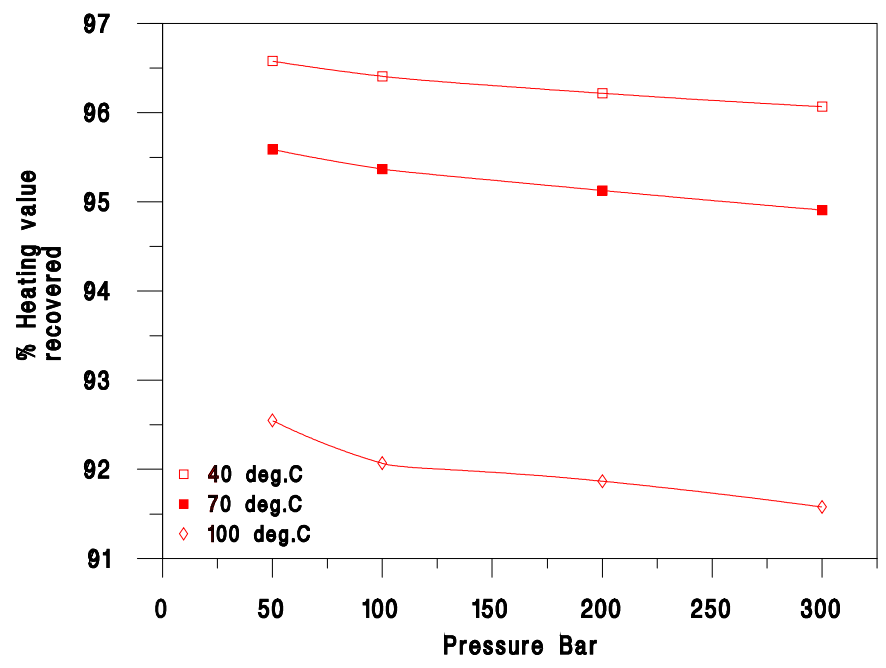

Figure 9. Effect of air pressure on heating value recovery of Silverdale coal.

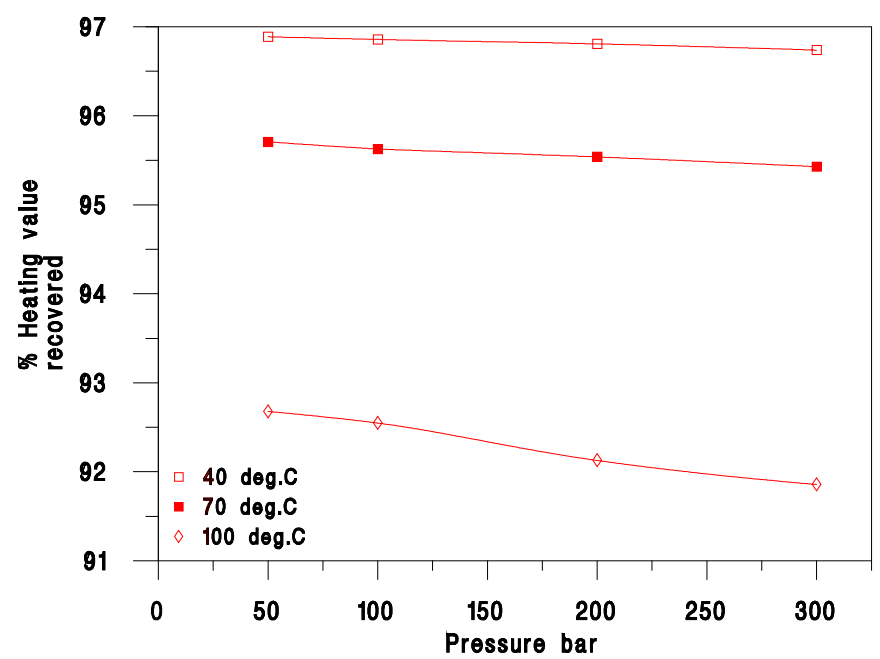

Figure 10. Effect of air pressure on heating value recovery of Harworth coal.

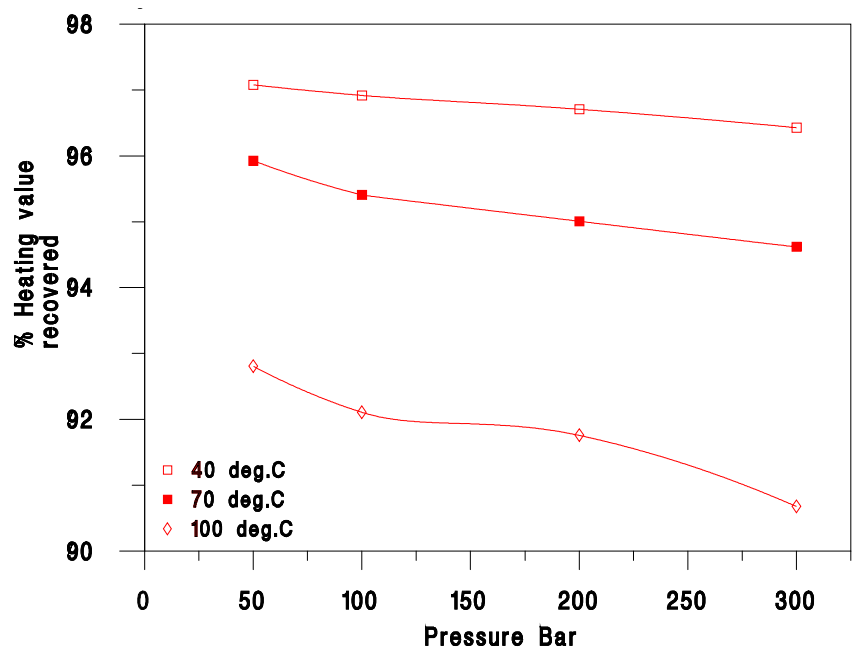


It was observed that sulphur removal was enhanced with increased pressure. The pyritic sulphur removal at 300 bar for Prince of Wales, Silverdale and Harworth coals was 77\%, 44\% and 51\% respectively, while, the organic sulphur removed was $30 \%, 14 \%$ and $31 \%$ respectively. It was also observed that there was a general decline in the rate of both pyritic and organic sulphur removal beyond 100 bars of air pressure. This decrease could be due to either or both of two reasons:

- The decrease in the $\mathrm{pH}$ of the leachate;

- The formation of an iron oxide (hematite) layer on the surface of pyrite particle(s) [22].

The reduction in the $\mathrm{pH}$ was due to the formation of sulphuric acid in the system [23]. This sulphuric acid was formed by the pyrite oxidation and since there was no $\mathrm{pH}$ buffer to maintain the $\mathrm{pH}$ of the reaction mixture, equilibrium of the pyrite oxidation was reached, resulting in a $\mathrm{pH}$ declining rate. It was also observed that the percentage pyritic sulphur removal in the case of Silverdale coal was less than the Harworth, which was less than Prince of Wales coal.

The reason for this difference in removal case of pyritic sulphur could be due to the fact that under the same conditions a particular amount of pyrite oxidation will generate a certain amount of acid in the system which in terms of percentage removed will produce a lower value from a higher sulphur content sample. Since these two coals had pyritic sulphur as the main part of the total sulphur content and acid production will favor the formation of insoluble elemental sulphur rather than a soluble sulphate [24], so the percentage of sulphur removed is less than Prince of Wales. It should be noted that the elemental sulphur formation is from the pyritic sulphur but due to the method of analysis is reported as organic sulphur. This phenomenon can be observed by some of the increased organic sulphur figures for the more severe oxidizing conditions compared to milder ones. The other reason for this difference in removal could be due to hematite layer formation on sulphur sites, as for discrete pyrite particles more sulphur sites are available while for finely disseminated pyrite these sites are limited.

While studying the effect of pressure on GCVs as shown in Figures 8-10 at various temperatures it was observed that pressure had no significant effect on GCV at a particular temperature. Beyond 100 bar the GCV values were observed to be constant. This may be due to temperature dependent activation of coal matrix active sites, as a generic similarity trend. The heating value recovery for Prince of Wales, Silverdale and Harworth varied from $97 \%$ to $92 \%, 97 \%$ to $92 \%$ and $97 \%$ to $91 \%$ respectively. The increase in oxygen content, which is a measure of carbon loss, is shown in Table 2. The percentage carbon loss was similar in all samples whereas the oxygen content varied for each sample. This \% increase in oxygen behavior could be related to formation of hematite and other oxide(s) on mineral matter in addition to being part of organic structure.

Table 2. Effect of air pressure on carbon and oxygen.

\begin{tabular}{ccc}
\hline Coal & Carbon Loss (\%) & Increase in Oxygen (\%) \\
\hline Prince of Wales & $3.9-6.7$ & $2.1-11.0$ \\
Silverdale & $3.9-6.9$ & $0.4-7.4$ \\
Harworth & $3.9-6.8$ & $10.9-15.2$ \\
\hline
\end{tabular}




\subsection{Effect of Pure Oxygen Pressure on Sulphur Removal}

One objective of this study was to evaluate whether overall high air pressure could give better removal than high oxygen partial pressure. A series of experiments was performed on Prince of Wales coal sample (B), in order to study the effect of oxygen pressure on sulphur removal. Pure standard oxygen obtained from BOC (BOC Industrial Gases, Surrey, UK) was used for these experiments. A special high pressure oxygen regulator was used for regulating the system pressure. Maximum pressure that could be attained by the bottle was 175 bar, so the highest partial pressure of oxygen was limited at this value. The reactions were carried out at four different pressures varying from 50-175 bar. Since the removal at $40{ }^{\circ} \mathrm{C}$ was negligible in the case of high air pressure so a higher temperature range was selected for this study varying from $70{ }^{\circ} \mathrm{C}$ to $150{ }^{\circ} \mathrm{C}$. Figures 11 and 12 show the effect of oxygen partial pressure on pyritic and organic sulphur removal, Figure 13 shows the heating value recovery of these experiments. The effect of temperature at constant pressure on pyritic and organic sulphur removal can be observed in Figure 14. In the high temperature oxydesulphurisation reactions, temperature is the most important parameter and has more effect than increasing pressure. Increasing the temperature from $20{ }^{\circ} \mathrm{C}$ to $100{ }^{\circ} \mathrm{C}$ at a particular pressure increased the amount of sulphur removal. It has been observed that the sulphur removal is also dependent on the temperature, so, the kinetics study of the reactions involved in the current process is also recommended as a future research task.

Figure 11. Effect of oxygen partial pressure on pyritic sulphur removal for Prince of Wales coal.

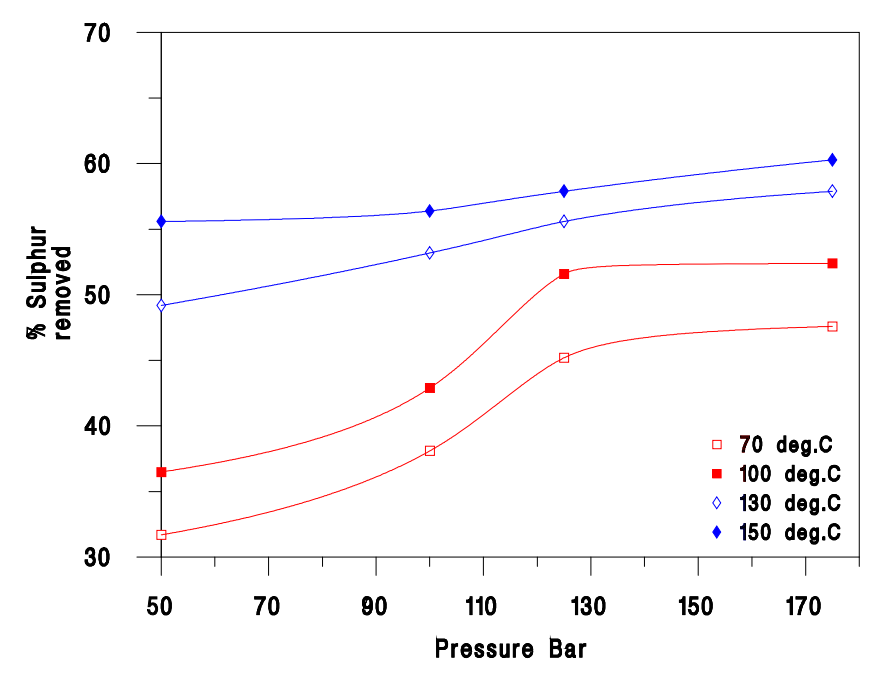


Figure 12. Effect of oxygen partial pressure on organic sulphur removal for Prince of Wales coal.

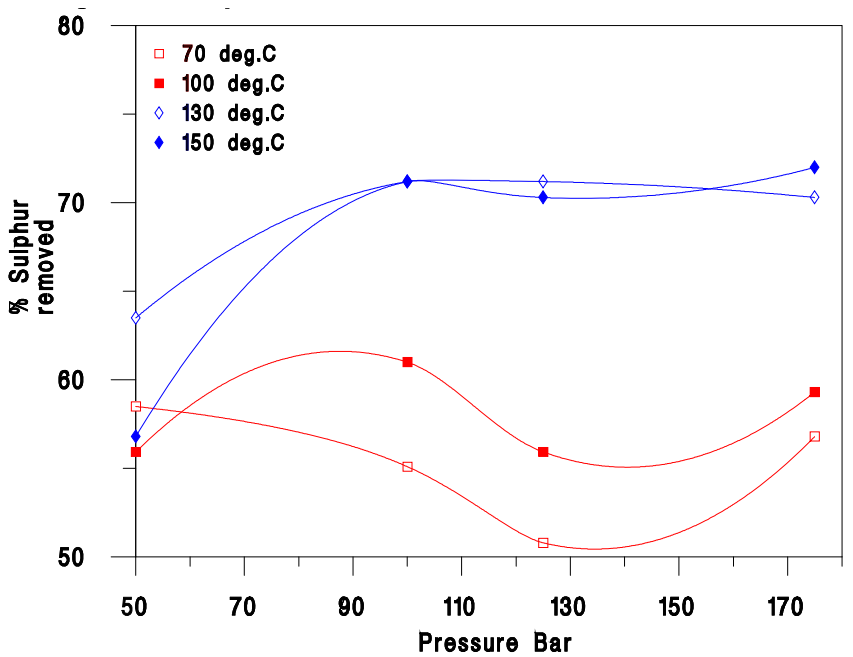

Figure 13. Effect of oxygen partial pressure on heating value recovery of Prince of Wales coal.

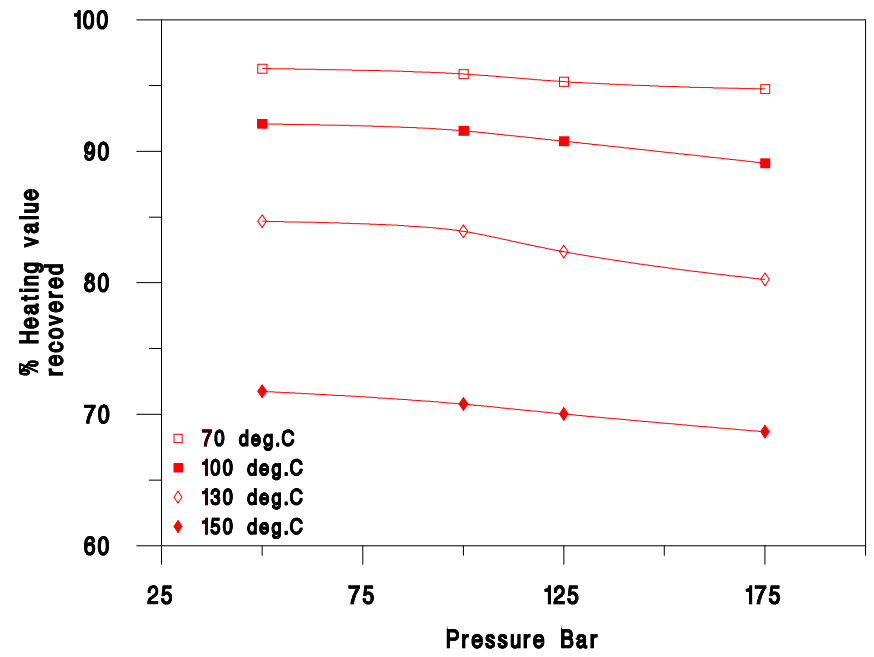

Figure 14. Effect of temperature on pyritic and organic sulphur removal at constant oxygen pressure for Prince of Wales coal.

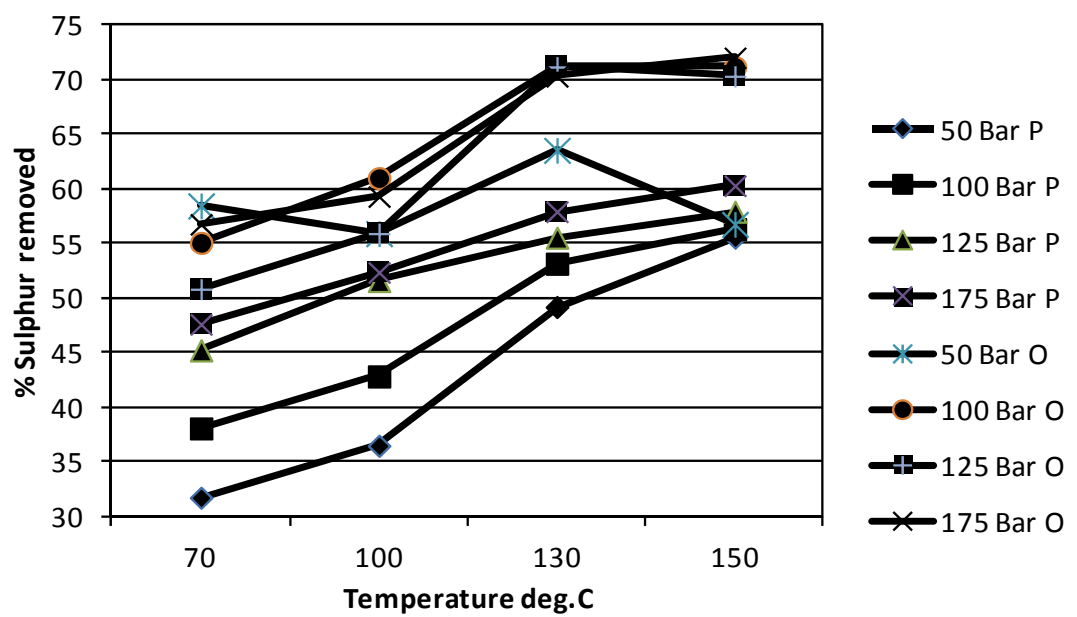


The porosimetric tests of the samples are also important to check the significance of time variable, but it was crucial for the current work because of the differences between the behaviors of the various samples due to the different pore size distribution of the three coals. Moreover, the capability of the solution to penetrate inside the sample does not depend only on the solution pressure, but also on the sample pore size distribution. Furthermore, the current study has been carried out to investigate the effect of pressure of the air and oxygen on the sulphur removal.

\section{Conclusions}

It can be concluded from the results that the effect of increasing air pressure on carbon loss for all the three coal samples was similar for a particular temperature, and so was the effect on oxygen content. Both of these changes resulted in a loss of heating value recovery. On an overall basis the experimental results demonstrate that the sulphur removal was enhanced with the increase in air pressure, particularly up to 100 bar, with only a small decrease in calorific value at a particular temperature. However increasing temperature was more important in sulphur removal than increasing pressure. It was observed that the sulphur analysis for the Silverdale and the Harworth coal samples were not as repeatable as that of Prince of Wales coal. The reason could be the presence of high ash content in those samples that might be causing interference in the sulphur analysis. This interference was not observed in the case of Prince of Wales coal.

The increase in pure oxygen pressure enhanced the sulphur removal as was case with high air pressure. The pyritic sulphur removal at 175 bar was $60 \%$, while the organic sulphur removal was $72 \%$. As observed in the previous case of air pressure a similar decrease was observed in the rate of both the pyritic and the organic sulphur removal beyond 100 bars. The reason is the same as discussed earlier in the case of high air pressure. It was also observed on comparing the results of similar reaction conditions of high oxygen partial pressure with high air pressure that although pure oxygen gave a slightly higher removal than air, the results were quite similar. The slightly higher removal of organic sulphur could be attributed to the smaller particle size of this sample.

In high temperature oxydesulphurisation reactions, temperature is the most important parameter and has more effect than increasing pressure. Conversely, increasing temperature reduces the heating value recovery. Pressure increases removal rate up to about 100 bar, but beyond that it has little effect. Increasing the temperature from $20^{\circ} \mathrm{C}$ to $100{ }^{\circ} \mathrm{C}$ at a particular pressure only increased the amount of sulphur removal by $10 \%$, but decreased the heat value recovery by $20 \%$.

Heating value recovery is a function of overall product constituents in terms of combustibles and non-combustibles i.e., carbon, hydrogen and ash-forming minerals. The decrease in ash content of the treated samples also produces again in heating value. In the case of exposure to higher temperature conditions, loss of coal matrix results in diminished heating values.

\section{Acknowledgments}

The authors gratefully acknowledge the financial support from Ministry of Science \& Technology, Government of Pakistan and the University of Sheffield for equipment and technical support. 


\section{References}

1. Vejahati, F.; Xu, Z.; Gupta, R. Trace elements in coal: Associations with coal and minerals and their behavior during coal utilization-A review. Fuel 2010, 89, 904-911.

2. Laskowski, J.S. Coal Surface Properties. In Developments in Mineral Processing; Elsevier: New York, NY, USA, 2001; Volume 14, pp. 31-94.

3. Hippo, E.J.; Crelling, J.C.; Palmer, S.E.; Kruge, M.A. Organic Sulfur Compounds in Coals. In Proceedings of 14th Annual Conference on Fuel, Electric Power Research Institute, Palo Alto, CA, USA, 3-5 January 1990; pp. 6/1-6/28.

4. Robinson, K. Reaction engineering of direct coal liquefaction. Energies 2009, 2, 976-1006.

5. Olszewska, D. Application of modified montmorillonite for desulphurisation during the combustion of hard coal. Fuel Process. Technol. 2011, 92, 2412-2419.

6. Olszewska, D. Application of XPS method in the research into Ni ion-modified montmorillonite as a $\mathrm{SO}_{2}$ sorbent. Fuel Process. Technol. 2012, 95, 90-95.

7. Marcewicz Kuba, A.; Olszewska, D. The activity of $\mathrm{SO}_{2}$ removal from combustion gases by the desonox type catalyst supported on montmorillonite and zeolite. Polish J.Chem.2008, 82, 43-47.

8. Zhu, B. Advanced environmental/energy technology: Desulfurisation and fuel cell cogeneration. Fuel Cells Bull. 1999, 2, 9-12.

9. Shui, H.; Cai, Z.; Xu, C. Recent advances in direct coal liquefaction. Energies 2010, 3, 155-170.

10. Chriswell, C.D.; Markuszewski, R.; Norton, G.A. Use of $\mathrm{NaOH}$ alone vs. $\mathrm{NaOH}-\mathrm{KOH}$ mixtures for the Removal of Sulphur and Ash from Coal by the Molten Caustic Leaching Process. In Processing and Utilisation of High Sulphur Coals IV; Dugan, P.R., Quigley, D.R., Attia, Y.A. Eds.; Elsevier: New York, NY, USA, 1991; pp. 385-397.

11. Norton, G.A.; Bluhm, D.D.; Markuszewski, R.; Chriswell, C.D. Application of Microwave Energy to Caustic Cleaning of Coal. In Processing and Utilisation of High Sulphur Coals IV; Dugan, P.R., Quigley, D.R., Attia, Y.A., Eds.; Elsevier: New York, NY, USA, 1991; pp. 425-438.

12. Demirbas, A.; Balat, M. Coal desulphurisation via different methods. Energy Sources 2004, 26, 541-550.

13. Yaman, S.; Kücükbayrak, S. Effect of oxydesulphurization on the combustion characteristics of coal. Thermochim. Acta 1997, 293, 109-115.

14. Palmer, S.R.; Hippo, E.J.; Dorai, X.A. Chemical coal cleaning using selective oxidation. Fuel 1994, 73, 161-169.

15. Palmer, S.R.; Hippo, E.J.; Dorai, X.A. Selective oxidation pretreatments for the enhanced desulphurisation of coal. Fuel 1995, 74, 193-200.

16. Palmer, S.R.; Hippo, E.J.; Kruge, M.A.; Crelling, J.C. Characterization and selective removal of organic sulfur from IIIinois basin coals. Coal Prep. 1992, 10, 93-106.

17. Pietrzak, R.; Wachowska, $\mathrm{H}$. The influence of oxidation with $\mathrm{HNO}_{3}$ on the surface composition of high-sulphur coals: XPS study. Fuel Process. Technol. 2006, 87, 1021-1029.

18. Pietrzak, R.; Grzybek, T.; Wachowska, H. XPS study of pyrite-free coals subjected to different oxidizing agents. Fuel 2007, 86, 2616-2624.

19. Jorjani, E.; Rezai, B.; Vossoughi, M.; Osanloo, M.; Abdollahi, M. Oxidation pretreatment for enhancing desulphurisation of coal with sodium butoxide. Miner. Eng. 2004, 17, 545-552. 
20. Demirbaş, A. Desulphurisation of coal using biomass ash. Energy Sources 2002, 24, 1099-1105.

21. British Standards Institution. Methods for Analysis and Testing of Coal and Coke. Ultimate Analysis of Coal-AMD 7689; BSI BS 1016-6, British Standards Institution: London, UK, 1993.

22. Burkin, A.R.; Edwards, A.M. The Formation of Insoluble Iron Oxide Coatings during the Alkali Pressure Leaching of Pyrite. In Proceedings of 6th International Congress of Moneral Processing, Cannes, France, 26 May-2 June 1963; pp. 159-167.

23. Warren, I.H. The generation of sulphuric acid from pyrite by pressure leaching. Aust. J. Appl. Sci. 1956, 7, 346-358.

24. Habashi, F. Recent Advances in Pressure Hydrometallurgy. In Proceedings of International Conference on Advances in Chemical Metallurgy, Bombay, India, 3-6 January 1979.

(C) 2013 by the authors; licensee MDPI, Basel, Switzerland. This article is an open access article distributed under the terms and conditions of the Creative Commons Attribution license (http://creativecommons.org/licenses/by/3.0/). 